Article

\title{
Efficiency of Skin Whitening Cream Containing Etlingera elatior Flower and Leaf Extracts in Volunteers
}

\author{
Nattawut Whangsomnuek ${ }^{1}$, Lapatrada Mungmai ${ }^{2}{ }^{\infty}$, Kriangsak Mengamphan $^{3,4}$ and \\ Doungporn Amornlerdpison 3,4,*iD \\ 1 Interdisciplinary Agriculture Program, Maejo University, Chiang Mai 50290, Thailand \\ 2 Cosmetic Science, School of Pharmaceutical Sciences, University of Phayao, Phayao 56000, Thailand \\ 3 Center of Excellence in Agricultural Innovation for Graduate Entrepreneur, Maejo University, \\ Chiang Mai 50290, Thailand \\ 4 Faculty of Fisheries Technology and Aquatic Resources, Maejo University, Chiang Mai 50290, Thailand \\ * Correspondence: doungpornfishtech@gmail.com; Tel.: +66-86-654-6966
}

Received: 4 June 2019; Accepted: 3 July 2019; Published: 6 July 2019

\begin{abstract}
Our previous research demonstrated that Etlingera elatior possesses whitening and anti-aging properties and also contains bioactive ingredients for cosmeceuticals. Therefore, this research work aimed to evaluate the efficiency of whitening cream containing both the flower and leaf extracts of E. elatior in human volunteers and their degree of skin irritation. Both the flower and leaf extracts were formulated as a cosmetic called "FL1 cream", which was assessed for its physical properties and underwent an accelerated stability test. The FL1 cream was also evaluated for skin irritation and its skin whitening effect among 24 healthy volunteers who used it for four weeks. The FL1 cream demonstrated good physical stability under the various conditions for three months, along with six cycles of heating/cooling. The irritation analysis showed that irritation reactions were absent in all volunteers. The efficiency of FL1 cream in improving the appearance of skin whitening was demonstrated by a significant $(p<0.05)$ and continuous decrease in melanin content compared with the initial value. Additionally, the $\mathrm{L}^{*}$ value was significantly and continuously increased after application of the FL1 cream. The highest melanin reduction was $6.67 \%$. The FL1 cream containing E. elatior extracts can be used as a whitening cream in cosmetics.
\end{abstract}

Keywords: clinical evaluation; Etlingera elatior; skin irritation; whitening cream

\section{Introduction}

Melanin is a pigment that plays an important role in skin protection against UV damage and is involved in pigmentary changes in skin color. It is formed through oxidation and by the amino acid tyrosine through cyclization. Tyrosinase is a melanogenic enzyme that catalyzes the rate-limiting synthetic for melanin production. Melanogenesis initially occurs through hydroxylation of L-tyrosine by tyrosinase converted to L-3,4-dihydroxyphenylalanine (L-DOPA) and by the oxidation of L-DOPA to DOPA-quinone, and eventually to melanin pigments [1,2]. Moreover, in another mechanism, a processes of protein glycosylation, Neu5Ac $\alpha(2-6)$ Gal- and possibly sialyl( $\alpha 2-3)$ gal-terminated glycans play an important role in melanogenesis and melanosome transfer to keratinocytes [3]. Overproduction and accumulation of melanin results in several skin pigmentation disorders, including solar lentigos (age spots), melasma, freckles, and post-inflammatory hyperpigmentation [4]. Therefore, whitening ingredients that result in inhibited tyrosinase activity, including inhibitory effects on melanogenesis and the melanosome transfer process, are essentially significant for reducing melanin synthesis. Tyrosinase inhibitors are obtained from both natural and synthetic sources, such as hydroquinone, arbutin, kojic 
acid, L-ascorbic acid, tranexamic acid, ellagic acid, and thiamidol [5]. Lately, Baswan et al. [6-8] reported that cytidine, though not a tyrosinase inhibitor, inhibits melanin synthesis and the melanosome transfer process by interfering with glycosylation processes. In current times, the desire to lighten the complexion has become popular in Asian people seeking beautiful-looking skin. Skin whitening products that propose to lighten the skin's appearance or treat hyper-pigmentation have become highly desirable in the cosmeceutical industries [9]. The use of skin whitening cosmetics has an important role in achieving skin lightening, as well as in diminishing dark spots on the skin $[10,11]$. Bioactive compounds from plants are gaining popularity for use as cosmetic ingredients in contemporary formulations, as they also contain vitamins, antioxidants, essential oils, proteins, phenolic compounds, and other active compounds [12,13]. Diverse bioactive compounds, including several phenolic compounds, have been reported to contain natural antioxidant compounds, along with having anti-aging, anti-microbial, anti-inflammatory, and tyrosinase-inhibiting actions. Further, these compounds in cosmetic products tend to be safer, biodegradable, more environmentally friendly, and more biologically active when compared with synthetic ingredients [14-16].

Etlingera elatior is a plant in the Zingiberaceae family that is widely cultivated in Southeast Asia as an ornamental flower or is locally consumed as food. The biological activities of E. elatior flowers and leaves have been reported over the past few decades. The presence of cosmeceutical properties that are proposed to improve skin appearance, such as antioxidant activity, has been suggested by ferric reducing antioxidant power (FRAP) assay, lipid peroxidation assay, 2, 2-diphenyl-1-picrylhydrazyl $(\mathrm{DPPH})$ radical scavenging, and inhibition of tyrosinase activity, as well as non-toxic properties, as shown by brine shrimp lethality assay [17-20].

In our previous study, E. elatior flower and leaf extracts were screened for their amino acid content, phenolic content, and biological activities for cosmetic properties, such as collagenase and tyrosinase inhibition, as well as antioxidant properties, via assay on 2, 2'-azino-bis (3-ethylbenzthiazoline-6-sulfonic acid) (ABTS), DPPH, and superoxide radical scavenging activities. Results indicated that the leaf extract exhibited the strongest antioxidant inhibitor property, higher than those of trolox and gallic acid, and showed the highest phenolic contents of isoquercetin, catechin, and gallic acid, as well as moderate anti-collagenase and amino acid contents. The flower extract showed greater potential to inhibit collagenase activity and more amino acids than the leaf extract, while also showing moderate phenolic compound levels and antioxidant activity. In addition, both the flower and leaf extracts were shown to be capable of suppressing melanogenesis through inhibiting tyrosinase activity [21].

On the basis of the previous study, the research team proposed developing a cosmetic cream for the purpose of skin whitening and with other beneficial properties. The cosmetic cream that was developed contained both the flower and leaf extracts of E. elatior together, in a formulation called "FL1 cream". The objective of this study was to evaluate the efficiency of the skin whitening cream containing both the flower and leaf extracts of E. elatior in human volunteers and to undertake an irritation test as well.

\section{Materials and Methods}

\subsection{Plant Sample}

E. elatior was purchased from a cultivator in the Reso District of Narathiwat Province, Thailand. The flowers and leaves were rinsed several times with distilled water, cut into small pieces, and subsequently shade-dried with a hot-air oven at $50{ }^{\circ} \mathrm{C}$. Dried samples were ground into a fine powder using a high-speed disintegrator machine.

\subsection{Plant Extraction}

An aqueous solution (1000 mL) including $100 \mathrm{~g}$ of powdered flowers or leaves was heated at $50{ }^{\circ} \mathrm{C}$ for $8 \mathrm{~h}$, then centrifuged at $4000 \mathrm{rpm}$ for $5 \mathrm{~min}$ at ambient temperature and filtered through 
Whatman No.1 filter paper. The filtrate extracts were concentrated by a rotary evaporator (KNF RC 900, KNF Neuberger, Trenton, NJ, USA) under vacuum pressure and then lyophilized using a freeze-dryer (Labogene CS 55-4, LaboGene A/S, Allerød, Denmark) to obtain the dried flower and leaf extracts.

\subsection{Tyrosinase Inhibition}

Tyrosinase inhibition was evaluated using the dopachrome method described by Masuda et al. [22], with some modifications. Solutions of $200 \mathrm{U} / \mathrm{mL}$ of tyrosinase from mushrooms and $2.5 \mathrm{mM}$ of L-DOPA (3, 4-dihydroxy-L-phenylalanine) were prepared with $20 \mathrm{mM}$ of phosphate buffer ( $\mathrm{pH}$ 6.8). The different concentrations and ratios of both flower and leaf extracts, comprising $0.5 \%$ and $1 \%$ in ratios of 1:1, 1:2, and 1:3 of flower/leaf extracts, were tested. Tyrosinase reactions were performed in a 96-well plate, with each well containing $20 \mu \mathrm{L}$ of different samples of the extracts, $40 \mu \mathrm{L}$ of tyrosinase solution, and $140 \mu \mathrm{L}$ of phosphate buffer. The 96-well plate was allowed to stand for $10 \mathrm{~min}$, and then the reaction was started by adding $40 \mu \mathrm{L}$ of L-DOPA solution (with phosphate buffer used as a control reaction). The 96-well plate was then incubated at an ambient temperature for 20 min, and the absorbance of tyrosinase activity was measured at $492 \mathrm{~nm}$ using a microplate reader (Biochrom EZ read 400) with kojic acid used as a reference substance. Each sample was completed with a blank plate of the sample test, except for the tyrosinase solution. The percentage of tyrosinase inhibition activity was obtained using the following equation:

$$
\text { Tyrosinase inhibition }(\%)=[\{(\mathrm{A}-\mathrm{B})-(\mathrm{C}-\mathrm{D})\} /(\mathrm{A}-\mathrm{B})] \times 100
$$

In this equation, $\mathrm{A}$ is the absorbance of the control reaction without a sample, $\mathrm{B}$ is the absorbance of the blank of the control reaction without a sample, $\mathrm{C}$ is the absorbance of the sample test with the presence of sample extracts, and D is the absorbance of the blank of the sample with the presence of sample extracts.

\subsection{Formulation of the Whitening Cream}

The formulations of FL1 cream containing E. elatior flower and leaf extracts are shown in Table 1. The process of preparation for the formulation included the addition of oil phase to the water phase, after which both phases were heated to $80^{\circ} \mathrm{C}$ before mixing. Stirring was continued using a mixer homogenizer until the temperature was approximately $50{ }^{\circ} \mathrm{C}$, then sodium hydroxide and preservative were added. Finally, the stirring was continued until the emulsion cooled to an ambient temperature.

Table 1. The formulations of FL1 cream containing Etlingera elatior flower and leaf extracts.

\begin{tabular}{|c|c|c|c|}
\hline Phase & Trade Name & INCI Name & $\%$ \\
\hline \multirow{8}{*}{$\begin{array}{c}\text { A } \\
\text { (Oil Phase) }\end{array}$} & \multirow{4}{*}{ Nikkomulese LH } & Glycerin (and) Hydrogenated lecithin (and) & \multirow{4}{*}{4.00} \\
\hline & & Hydroxypropyl methylcellulose stearoxy & \\
\hline & & Ether (and) Squalane (and) Sodium methyl & \\
\hline & & stearoyl taurate & \\
\hline & DC 350 & Dimethicone & 3.00 \\
\hline & Squalane & Squalane & 5.00 \\
\hline & Cetyl alcohol & Cetyl alcohol & 0.30 \\
\hline & Stearyl alcohol & Stearyl alcohol & 0.30 \\
\hline \multirow{6}{*}{$\begin{array}{c}\text { B } \\
\text { (Water Phase) }\end{array}$} & $\mathrm{Na}_{2}$ EDTA & Disodium EDTA & 0.10 \\
\hline & Glycerin & Glycerin & 3.00 \\
\hline & Butylene glycol & Butylene glycol & 4.00 \\
\hline & $\begin{array}{l}\text { Carbopol ultrez } 21 \\
\text { polymer }\end{array}$ & $\begin{array}{c}\text { Acrylates/C10-30 alkyl acrylate } \\
\text { crosspolymer }\end{array}$ & 0.50 \\
\hline & 1Flower/1leaf extract & Etlingera elatior & 1.00 \\
\hline & DI water & Aqua & q.s. 100 \\
\hline C & $\mathrm{NaOH}(18 \% \mathrm{w} / \mathrm{v})$ & Sodium hydroxide (for adjusting $\mathrm{pH}$ to 5.5) & 0.30 \\
\hline $\mathrm{D}$ & Spectrastat BHL & $\begin{array}{c}\text { Caprylhydroxamic acid (and) } \\
\text { 1,2-hexanediol (and) butylene glycol }\end{array}$ & 2.00 \\
\hline
\end{tabular}




\subsection{Stability Testing}

The stability was evaluated by the centrifugation method at $4000 \mathrm{rpm}$ and at $20^{\circ} \mathrm{C}$ for $30 \mathrm{~min}$ to determine the mechanical stress [23]. Accelerated stability testing was also performed in various conditions under room temperature, $4{ }^{\circ} \mathrm{C}$, and $45{ }^{\circ} \mathrm{C}$ for three months and six cycles of the heating/cooling method $\left(45^{\circ} \mathrm{C}, 48 \mathrm{~h}\right.$ alternated with $4{ }^{\circ} \mathrm{C}, 48 \mathrm{~h}$ for 1 cycle) [24]. During the stability testing, the physiochemical appearance of the cream, including any change in color or odor, $\mathrm{pH}$, viscosity, phase separation, and precipitation, was investigated.

\subsection{Clinical Evaluation in Volunteers}

The skin irritation testing and skin whitening efficiency testing on healthy volunteers in this study were approved by the University of Phayao Human Ethics Committee, Thailand (Project identification code: 3/018/61). The efficiency evaluations were performed on 24 healthy volunteers (aged 25-55, $n=24)$. They were investigated for any skin disease and cosmetics allergy history. Before being enrolled in the study, each volunteer received the information protocol that contained the terms and conditions of the clinical testing and signed an informed consent form.

\subsection{Skin Irritation Testing}

The skin irritation testing was done using a modified Draize model, as described by Bashir and Maibach [25], using Finn chambers ${ }^{\circledR}$. Skin irritation was performed on the upper outer arm (left-hand side) of volunteers, with each chamber saturated by FL1 cream containing E. elatior extracts, $1 \% \mathrm{w} / \mathrm{v}$ of sodium lauryl sulfate (used as a positive reaction), and deionized water (as a negative reaction), before being covered for $48 \mathrm{~h}$. Subsequently, we observed the erythema and edema at 1, 24, and $48 \mathrm{~h}$ after removing the patch. Each of the test substances were evaluated based on the primary dermal irritation index (PDII) using the Draize scoring system.

\subsection{Efficiency Testing in Human Volunteers}

The skin improvement test of the whitening cream was performed with 24 healthy volunteers. They were tested for reduced melanin content after applying the FL1 cream twice a day, morning and evening, on the skin of their left forearm for four weeks. Following Leelapornpisid et al. [24], an untreated area on each volunteer's right forearm was used as a control. Before the study, the volunteers were rested in a suitable room at $20{ }^{\circ} \mathrm{C}$ and $50 \%$ relative humidity (RH) for $15 \mathrm{~min}$ [26]. The study procedures were conducted on Day 0 for the initial value, then on the 1st, 2nd, 3rd, and 4th weeks. The melanin content and CIE- ${ }^{*}$ value were measured using the skin color probe from DermaLab ${ }^{\circledR}$ Combo (Cortex Technology). Finally, the volunteers were asked to fill out a questionnaire regarding their satisfaction with the whitening cream on Day 30. The ability of the FL1 cream to reduce melanin pigment was obtained using the following equation:

$$
\text { Reduction activity }(\%)=\left[\left(\mathrm{M}_{\mathrm{d} 0}-\mathrm{M}_{\mathrm{dm}}\right) /\left(\mathrm{M}_{\mathrm{d} 0}\right)\right] \times 100 \text {. }
$$

In this equation, $\mathrm{M}_{\mathrm{d} 0}$ is the melanin content on the initial day and $\mathrm{M}_{\mathrm{dm}}$ is the melanin content on the day of measuring.

\subsection{Statistical Analysis}

The statistical analysis was conducted using the Statistical Package for the Social Sciences (SPSS), version 17.0 for Windows. Viscosity data were analyzed by the use of a one-way analysis of variance (ANOVA) with Tukey's HSD test. A repeated measures ANOVA with pairwise comparisons by the Bonferroni method was used to analyze the skin whitening effect in volunteers. Statistical significance was determined to be at $p<0.05$. 


\section{Results and Discussion}

\subsection{Tyrosinase Inhibition Activity}

Tyrosinase is a crucial rate-limiting enzyme in direct melanin synthesis. Therefore, cosmetic products containing tyrosinase inhibitors are becoming more commonly used for their skin whitening properties [27]. In our previous study, flower and leaf at $10 \mathrm{mg} / \mathrm{mL}$ showed tyrosinase inhibition activity of $24.37 \% \pm 0.52 \%$ and $31.48 \% \pm 1.28 \%$, respectively [21]. This study aimed to develop a cosmetic cream containing both the flower and leaf extracts of E. elatior together for the main purpose of skin whitening. Therefore, a suitable concentration and ratio of mixed flower and leaf extracts were investigated. Mushroom tyrosinase was used to determine the role of E. elatior in the process of melanogenesis. As shown in Figure 1, the results demonstrated that all concentrations of mixed flower and leaf extracts inhibited tyrosinase activity. In addition, flower and leaf extracts at a concentration of $1 \%$ and in a ratio of $1: 1$ exhibited the highest tyrosinase inhibition activity at $74.61 \% \pm 0.00 \%$. These results indicate that $1 \%$ of mixed flower and leaf extracts of E. elatior in a ratio of 1:1 is a suitable concentration for use in formulating the cosmetic "FL1". Furthermore, methanol flower and leaf extracts did not show a cytotoxic effect on WRL-68 (human liver) or Vero (African green monkey kidney), or in an Artemia salina lethality bioassay [18,20]. Hence, they might be promising for safe use in cosmetic products.

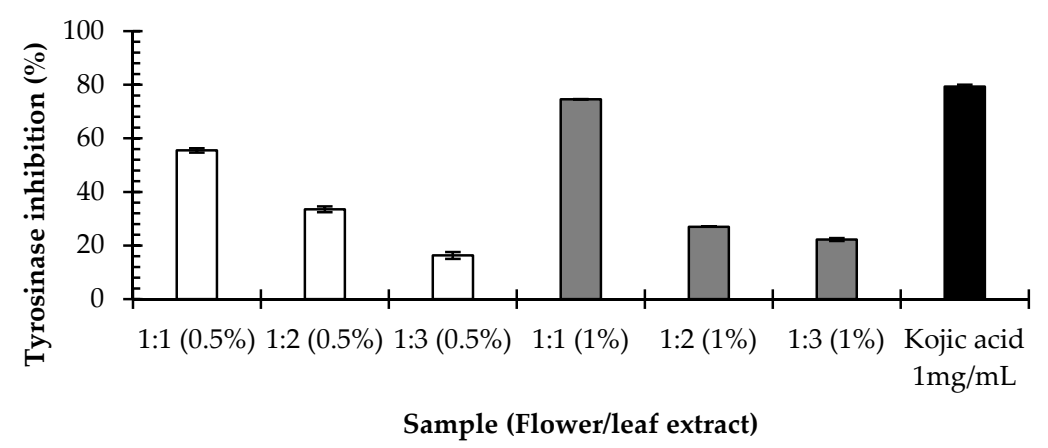

Figure 1. The effect of mixed E. elatior flower and leaf extracts on tyrosinase inhibition activity.

\subsection{Formulation of the Whitening Cream}

In this study, the FL1 cream was evaluated for its physical properties, including $\mathrm{pH}$, color, viscosity (Pa.s), and by centrifugation test, as shown in Table 2. After cosmetic formulation, the physical appearance of the FL1 cream was assessed. The texture was found to be tender, with very good spreadability and a soft feeling on the skin. The FL1 cream was stable and showed no phase separation when centrifuged at $4000 \mathrm{rpm}$ for $30 \mathrm{~min}$.

Table 2. The physical properties of the FL1 cream formulation.

\begin{tabular}{|c|c|c|c|c|c|c|}
\hline \multirow{2}{*}{ Parameters } & \multirow{2}{*}{$\mathrm{pH}$} & \multicolumn{3}{|c|}{ Color } & \multirow{2}{*}{$\begin{array}{l}\text { Viscosity } \\
\text { (Pa.s) }\end{array}$} & \multirow{2}{*}{$\begin{array}{c}\text { Centrifugation } \\
\text { Test }\end{array}$} \\
\hline & & $\mathbf{L}^{*}$ & $a^{*}$ & $\mathbf{b}^{*}$ & & \\
\hline FL1 cream & 5.5 & $60.69 \pm 0.63$ & $2.47 \pm 0.26$ & $20.43 \pm 1.08$ & $6.20 \pm 0.02$ & Stable \\
\hline
\end{tabular}

\subsection{Stability Testing}

Stability testing under accelerated conditions showed that the $\mathrm{pH}$ of the cream kept in all conditions did not change after testing, and separation and precipitation of the FL1 cream were not observed (as shown in Table 3). The viscosity under all conditions compared to the start condition was maintained at room temperature and $4{ }^{\circ} \mathrm{C}$ and under heating/cooling cycles was not significantly different $(p>0.05)$. At $45^{\circ} \mathrm{C}$, there was an obvious decrease in viscosity, which may be the effect of heat. Moreover, the 
physical properties of color under all conditions were also significantly stable $(p>0.05)$, and odor was stable after the stability tests (data not shown). Therefore, FL1 could be stored long term without any change in the $\mathrm{pH}$, color, or viscosity.

Table 3. The stability testing results of FL1 cream after three months and after heating/cooling for six cycles.

\begin{tabular}{ccccccc}
\hline \multirow{2}{*}{ Conditions } & \multirow{2}{*}{$\mathbf{p H}$} & \multirow{2}{*}{$\begin{array}{c}\text { Viscosity } \\
\text { (Pa.s) }\end{array}$} & $\begin{array}{c}\text { Separation and } \\
\text { Precipitation }\end{array}$ & & \multicolumn{3}{c}{ Color } \\
\cline { 5 - 7 } & & & & $\mathbf{L}^{*}$ & $\mathbf{a}^{*}$ & $\mathbf{b}^{*}$ \\
\hline Initial & 5.5 & $6.20 \pm 0.02^{\mathrm{a}}$ & $\mathrm{x}$ & $60.69 \pm 0.63^{\mathrm{a}}$ & $2.47 \pm 0.26^{\mathrm{a}}$ & $20.43 \pm 1.08^{\mathrm{a}}$ \\
\hline $\mathrm{RT}$ & 5.5 & $6.15 \pm 0.02^{\mathrm{a}}$ & $\mathrm{x}$ & $60.18 \pm 0.39^{\mathrm{a}}$ & $2.40 \pm 0.23^{\mathrm{a}}$ & $20.07 \pm 0.89^{\mathrm{a}}$ \\
$4^{\circ} \mathrm{C}$ & 5.5 & $6.17 \pm 0.06^{\mathrm{a}}$ & $\mathrm{x}$ & $60.09 \pm 0.34^{\mathrm{a}}$ & $2.49 \pm 0.23^{\mathrm{a}}$ & $19.75 \pm 0.84^{\mathrm{a}}$ \\
$45^{\circ} \mathrm{C}$ & 5.5 & $6.01 \pm 0.03^{\mathrm{b}}$ & $\mathrm{x}$ & $60.28 \pm 0.95^{\mathrm{a}}$ & $2.66 \pm 0.64^{\mathrm{a}}$ & $21.62^{\mathrm{b}} \pm 0.45^{\mathrm{a}}$ \\
$\mathrm{H} / \mathrm{C}$ & 5.5 & $6.15 \pm 0.05^{\mathrm{a}}$ & $\mathrm{x}$ & $60.78 \pm 0.51^{\mathrm{a}}$ & $2.51 \pm 0.41^{\mathrm{a}}$ & $20.13 \pm 0.24^{\mathrm{a}}$ \\
\hline
\end{tabular}

Values are expressed as means \pm standard deviation. For the viscosity and color values, not sharing the same letter in each column indicates significant difference at $p<0.05$. RT $=$ Room temperature; $\mathrm{H} / \mathrm{C}=$ Heating/cooling conditions.

\subsection{Irritation Testing}

The dermatological test for irritation and allergy effects on human volunteers was performed to ensure the safety of the FL1 cream. The 24 volunteers were tested with FL1 cream, $1 \%$ w/v of sodium lauryl sulfate, and deionized water. The results are shown in Table 4. The FL1 cream was non-irritating, with a low Primary Dermal Irritation Index value (PDII < 0.5), whereas sodium lauryl sulfate (SLS), which was used as a positive control, was revealed to be slightly irritating (PDII range from 0.5 to 2.0).

Table 4. The Primary Dermal Irritation Index (PDII) value and skin irritation reaction observed for FL1 cream.

\begin{tabular}{ccc}
\hline Test Substances & PDII & Classification of Skin Irritation \\
\hline FL1 cream & 0.00 & Non-irritating \\
$1 \%$ w $/ \mathrm{v}$ SLS (positive) & 0.80 & Slightly irritating \\
DI water (negative) & 0.00 & Non-irritating \\
\hline
\end{tabular}

\subsection{Skin Whitening Testing}

The whitening effect of FL1 cream containing E. elatior extracts was evaluated by comparison before the treatment. This was done by measuring the amount of melanin using DermaLab ${ }^{\circledR}$ Combo (Cortex Technology, Hadsund, Denmark) to confirm the efficiency of this product. As shown in Table 5, the results demonstrated that the melanin content in the skin when using FL1 cream was significantly and continuously decreased after one week, until week three of testing $(p<0.05)$. In week four, the melanin content increased, which may be due to the time of testing (March 2019 to April 2019) in Thailand being in the summer season. This period has a corresponding increase in UV exposure, which is one of the causes of melanin synthesis [28,29]; the UV index is shown in Figure 2. Furthermore, the $\mathrm{L}^{*}$ value was used for indicating skin lightening after applying the FL1 cream, and it was found that the $\mathrm{L}^{*}$ value continuously increased from the 1 st to the 3 rd week $(p<0.05)$, as did the melanin content. For the untreated areas, the data still showed constant melanin content until week two of testing with no significant difference $(p>0.05)$, but the content increased from the 3 rd to the 4 th week. However, the $\mathrm{L}^{*}$ value of the untreated area was slightly increased until week three and slightly decreased subsequently until week four of testing. In addition, the melanin reduction activity of the FL1 cream reached its highest level of $6.67 \%$ after three weeks of testing (Figure 3). There were no significant differences in melanin reduction observed between the FL1-treated and untreated areas of the volunteers during the testing period. These results indicated that E. elatior flower and leaf extracts achieved a decent skin whitening effect on human volunteers. 
Table 5. The melanin content $(\%)$ and $L^{*}$ value after application of the FL1 cream for four weeks.

\begin{tabular}{|c|c|c|c|c|c|c|}
\hline Test & Parameter & Baseline & Week 1 & Week 2 & Week 3 & Week 4 \\
\hline \multirow{2}{*}{ FL1 cream } & $\begin{array}{c}\text { Melanin } \\
\text { content (\%) }\end{array}$ & $36.00 \pm 0.33^{a}$ & $35.13 \pm 0.38^{b}$ & $33.93 \pm 0.53^{c}$ & $33.60 \pm 0.44^{c}$ & $35.39 \pm 0.55^{a b}$ \\
\hline & $\mathrm{L}^{*}$ value & $37.39 \pm 0.40^{\mathrm{a}}$ & $38.54 \pm 0.47^{b}$ & $39.41 \pm 0.47^{c}$ & $41.00 \pm 0.65^{\mathrm{d}}$ & $39.13 \pm 0.70 b c$ \\
\hline \multirow{2}{*}{$\begin{array}{l}\text { Untreated } \\
\text { area }\end{array}$} & $\begin{array}{c}\text { Melanin } \\
\text { content (\%) }\end{array}$ & $36.44 \pm 0.37^{a}$ & $36.15 \pm 0.34^{a}$ & $36.01 \pm 0.34^{\mathrm{a}}$ & $37.13 \pm 0.39 a b$ & $37.52 \pm 0.47^{b}$ \\
\hline & $\mathrm{L}^{*}$ value & $37.57 \pm 0.42^{\mathrm{a}}$ & $38.07 \pm 0.47^{a b}$ & $38.33 \pm 0.46^{b}$ & $37.95 \pm 0.42^{\mathrm{a}}$ & $36.54 \pm 0.80^{\mathrm{a}}$ \\
\hline
\end{tabular}

Values are expressed as means \pm standard error. For each parameter of each sample test, not sharing the same letter in each row indicates significant difference at $p<0.05$.

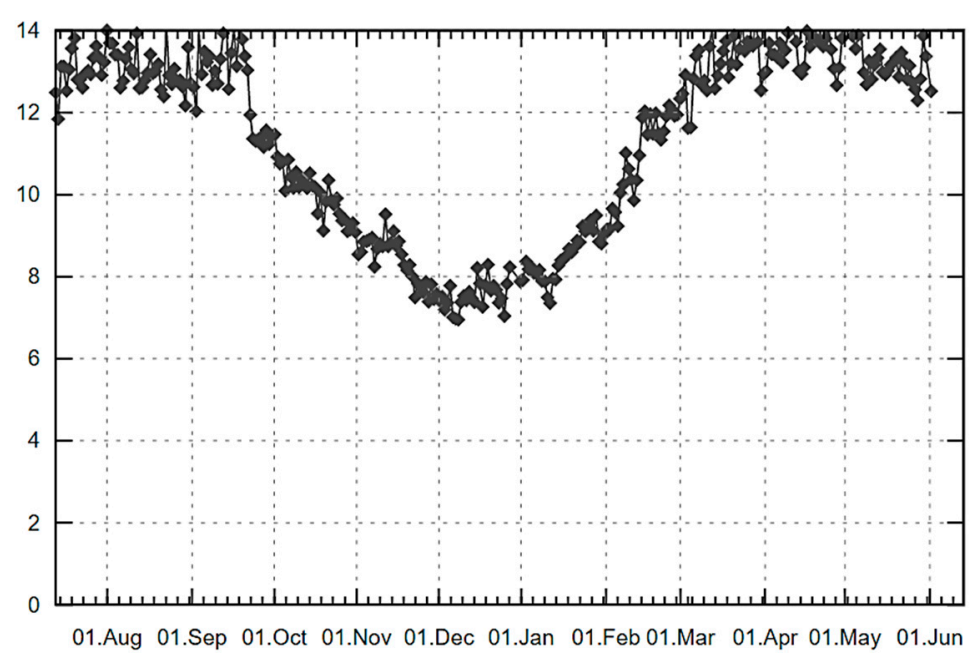

Figure 2. The UV index in Chiang Mai city, Thailand, from August 2018 to June 2019, (C) weatheronline.co.uk [36].

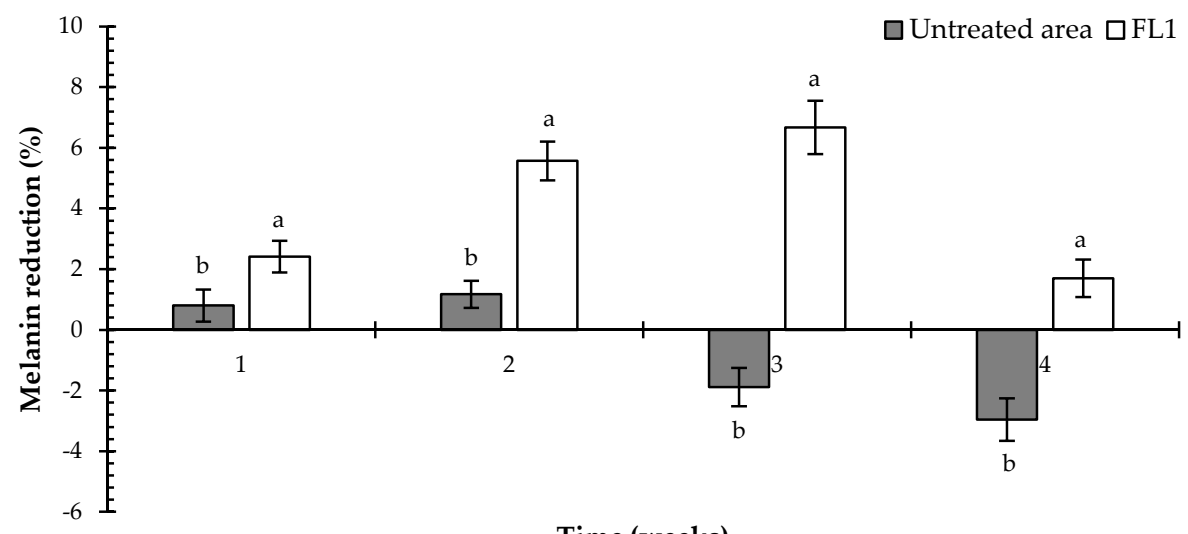

Time (weeks)

Figure 3. The effect of FL1 cream on melanin reduction. Values are expressed as means \pm standard error. For groups in the same week, not sharing the same letter indicates significant difference at $p<0.05$.

Traditionally, commercial skin whitening agents for suppressing tyrosinase activity have included hydroquinone, arbutin, kojic acid, azelaic acid, ascorbic acid, ellagic acid, and tranexamic acid. These have been widely used in formulations of cosmetic products, with some drawbacks and side effects $[27,30]$. In the past few decades, research has demonstrated that natural bioactive compounds are increasingly being used in whitening cosmetic formulations. In addition, there are several plant extracts that have been shown to be effective agents to suppress the overproduction of melanin or to regulate melanin synthesis, such as Cassia fistula flowers [31], Asphodelus microcarpus [32], Magnolia officinalis [33], Dendrobium tosaense [34], and Kummerowia striata [35]. The results of the present study indicated that 
extracts of E. elatior flowers and leaves achieved a decent skin whitening effect on human volunteers; therefore, these extracts act as the active whitening ingredient in FL1 cream.

\subsection{Satisfaction Testing}

The volunteers were asked to fill in a questionnaire after using the FL1 cream for 30 days. The satisfaction level was determined using a 5-point scale, in which the point value represented the volunteers' feelings about how well the product worked, from very well (5) to very poorly (1). The results revealed that the volunteers' satisfaction with the FL1 cream was high, with responses between "well" and "very well" for all areas measured, as shown in Figure 4. Further, the most satisfying areas of the FL1 cream were the softness of the cream, its spreadability, and overall satisfaction, which had a mean of 4.67, while the lowest was the cream's glossiness, with a mean of 4.33. Additionally, none of the volunteers suffered skin irritation or allergic reactions during the test period.

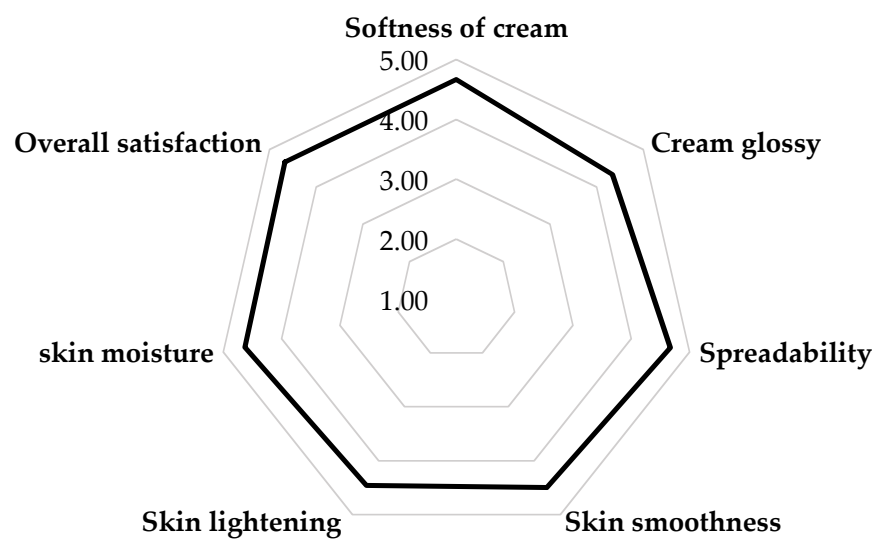

Figure 4. The satisfaction of the volunteers with the FL1 cream.

\section{Conclusions}

The present study demonstrated that both the flower and leaf extracts of E. elatior could potentially be a natural whitening ingredient for commercial cosmetics. In our previous study, aqueous extracts of the flowers and leaves revealed the presence of isoquercetin, catechin, and gallic acid [21], which are capable of inhibiting tyrosinase activity, leading to a skin lightening effect useful in cosmetic applications [37-39]. The results revealed that with the use of the cream, the melanin content decreased and the $L^{*}$ value increased compared with initial values. The data showed an increased melanin reduction after application of FL1 to the skin when compared to an untreated area. The FL1 cream was found to be safe, with no reported irritation of the skin of the volunteers, and it was also found to be satisfactory by the volunteers. Therefore, FL1 cream containing E. elatior flower and leaf extracts might be an effective whitening cosmetic for improving skin appearance.

Author Contributions: Conceptualization, N.W., and D.A.; methodology, N.W., D.A., and, L.M.; formal analysis, N.W. and D.A.; investigation, N.W., D.A., and, L.M.; resources, D.A., and K.M.; supervision, D.A., L.M., and K.M.; writing-original draft, N.W., and D.A.

Funding: This research was funded by the Thailand Research Fund (TRF) under the program of Research and Researcher for Industry (RRi), grant number PHD59I0032.

Acknowledgments: The authors are grateful to the Center of Excellence in Agricultural Innovation for Graduate Entrepreneur, Graduate School of Maejo University for their material support.

Conflicts of Interest: The authors declare no conflict of interest.

\section{References}

1. D'Orazio, J.; Jarrett, S.; Amaro-Ortiz, A.; Scott, T. UV radiation and the skin. Int. J. Mol. Sci. 2013, 14, 12222-12248. [CrossRef] [PubMed] 
2. Kim, C.S.; Noh, S.G.; Park, Y.; Kang, D.; Chun, P.; Chung, H.Y.; Jung, H.J.; Moon, H.R. A potent tyrosinase inhibitor, (E)-3-(2,4-Dihydroxyphenyl)-1-(thiophen-2-yl)prop2-en-1-one, with anti-melanogenesis properties in $\alpha$-MSH and IBMX-induced B16F10 melanoma cells. Molecules 2018, 23, 2527. [CrossRef] [PubMed]

3. Diwaker, G.; Klump, V.; Lazova, R.; Pawelek, J. Evidence for glycosylation as a regulator of the pigmentary system: key roles of sialyl $(\alpha 2-6)$ gal/GalNAc-terminated glycans in melanin synthesis and transfer. Glycoconj J. 2015, 32, 413-420. [CrossRef] [PubMed]

4. Ortonne, J.P.; Bissett, D.L. Latest insights into skin hyperpigmentation. JIDSP 2008, 13, 10-14. [CrossRef] [PubMed]

5. Zolghadri, S.; Bahrami, A.; Hassan Khan, M.T.; Munoz-Munoz, J.; Garcia-Molina, F.; Garcia-Canovas, F.; Saboury, A.A. A comprehensive review on tyrosinase inhibitor. J. Enzyme Inhib. Med. Chem. 2019, 34, $279-309$. [CrossRef] [PubMed]

6. Baswan, S.M.; Leverett, J.; Pawelek, J. Clinical evaluation of the lightening effect of cytidine on hyperpigmented skin. J. Cosmet. Dermatol. 2019, 18, 278-285. [CrossRef] [PubMed]

7. Baswan, S.M.; Yim, S.; Leverett, J.; Pawelek, J. LB1591 In-vitro and in-vivo evaluation of skin lightening efficacy of cytidine. J. Investig. Dermatol. 2018, 138, B21. [CrossRef]

8. Baswan, S.M.; Yim, S.; Leverett, J.; Scholten, J.; Pawelek, J. Cytidine decreases melanin content in a reconstituted three-dimensional human epidermal model. Arch. Dermatol. Res. 2019, 311, 249-250. [CrossRef]

9. Lorz, L.R.; Yoo, B.C.; Kim, M.Y.; Cho, J.Y. Anti-wrinkling and anti-melanogenic effect of Pradosia mutisii methanol extract. Int. J. Mol. Sci. 2019, 20, 1043. [CrossRef]

10. Sahin, S.C. The potential of Arthrospira platensis extract as a tyrosinase inhibitor for pharmaceutical or cosmetic applications. S. Afr. J. Bot. 2018, 119, 236-243. [CrossRef]

11. Wang, G.H.; Chen, C.Y.; Lin, C.P.; Huang, C.L.; Liu, C.H.; Cheng, C.Y.; Chung, Y.C. Tyrosinase inhibitor and antioxidant activities of three Bifidobacterium bifidum-fermented herb extracts. Ind. Crops Prod. 2016, 89, 376-382. [CrossRef]

12. Ribeiro, A.S.; Estanqueiro, M.; Oliveira, M.B.; Lobo, J.M.S. Main benefits and applicability of plant extracts in skin care products. Cosmetics 2015, 2, 48-65. [CrossRef]

13. Mukherjee, P.K.; Maity, N.; Nema, N.K.; Sarkar, B.K. Bioactive compounds from natural resources against skin aging. Phytomedicine 2011, 19, 64-73. [CrossRef] [PubMed]

14. Li, F.X.; Li, F.H.; Yang, Y.X.; Yin, R.; Ming, J. Comparison of phenolic profiles and antioxidant activities in skins and pulps of eleven grape cultivars (Vitis vinifera L.). J. Integr. Agric 2019, 18, 1148-1158. [CrossRef]

15. Działo, M.; Mierziak, J.; Korzun, U.; Preisner, M.; Szopa, J.; Kulma, A. The potential of plant phenolics in prevention and therapy of skin disorders. Int. J. Mol. Sci. 2016, 17, 160. [CrossRef] [PubMed]

16. Soto, M.L.; Falqué, E.; Domínguez, H. Relevance of natural phenolics from grape and derivative products in the formulation of cosmetics. Cosmetics 2015, 2, 259-276. [CrossRef]

17. Ghasemzadeh, A.; Jaafar, H.Z.E.; Rahmat, A.; Ashkani, S. Secondary metabolites constituents and antioxidant, anticancer and antibacterial activities of Etlingera elatior (Jack) R.M.Sm grown in different locations of Malaysia. BMC Complement. Altern. Med. 2015, 15, 335. [CrossRef] [PubMed]

18. Chan, E.W.C.; Lim, Y.Y.; Wong, S.K. Phytochemistry and pharmacological properties of Etlingera elatior: A review. Phcog. J. 2011, 3, 6-10. [CrossRef]

19. Chan, E.W.C.; Lim, Y.Y.; Tan, S.P. Standardised herbal extract of chlorogenic acid from leaves of Etlingera elatior (Zingiberaceae). Phcog. Res. 2011, 3, 178-183. [CrossRef]

20. Lachumy, S.J.T.; Sasidharan, S.; Sumathy, V.; Zuraini, Z. Pharmacological activity, phytochemical analysis and toxicity of methanol extract of Etlingera elatior (torch ginger) flowers. Asian Pac. J. Trop. Med. 2010, 769-774. [CrossRef]

21. Whangsomnuek, N.; Mungmai, L.; Mengamphan, K.; Amornlerdpison, D. Anti-aging and whitening properties of bioactive compounds from Etlingera elatior (Jack) R.M.Sm. flower and leaf extracts for cosmetic applications. Maejo. Int. J. Sci. Tech. In Press.

22. Masuda, T.; Yamashita, D.; Takeda, Y.; Yonemori, S. Screening for tyrosinase inhibitors among extracts of seashore plants and identification of potent inhibitors from Garcinia. subelliptica. Biosci. Biotechnol. Biochem. 2005, 69, 197-201. [CrossRef] [PubMed]

23. Censi, R.; Peregrina, D.V.; Lacava, G.; Agas, D.; Lupidi, G.; Sabbieti, M.G.; Martino, P.D. Cosmetic formulation based on an açai extract. Cosmetics 2018, 5, 48. [CrossRef] 
24. Leelapornpisid, P.; Mungmai, L.; Sirithunyalug, B.; Jiranusornkul, S.; Peerapornpisal, Y. A novel moisturizer extracted from freshwater macroalga [Rhizoclonium hieroglyphicum (C.Agardh) Kützing] for skin care cosmetic. Chiang Mai. J. Sci. 2014, 41, 1195-1207.

25. Bashir, S.J.; Maibach, H.I. In vivo irritation. In Handbook of Cosmetic Science and Technology, 3rd ed.; Barel, A.O., Paye, M., Maibach, H.I., Eds.; Taylor and Francis Group: Vanderbilt Avenue, New York, NY, USA, 2009; pp. 471-479.

26. Jaros, A.; Zasada, M.; Budzisz, E.; Dębowska, R.; Gębczyńska-Rzepka, M.; Rotsztejn, H. Evaluation of selected skin parameters following the application of $5 \%$ vitamin C concentrate. J. Cosmet. Dermatol. 2019, 18, 236-241. [CrossRef] [PubMed]

27. Pillaiyar, T.; Manickam, M.; Namasivayam, V. Skin whitening agents: medicinal chemistry perspective of tyrosinase inhibitors. J. Enzyme Inhib. Med. Chem. 2017, 32, 403-425. [CrossRef] [PubMed]

28. Pintus, F.; Spanò, D.; Corona, A.; Medda, R. Antityrosinase activity of Euphorbia characias extracts. Peer] 2015, 3, e1305. [CrossRef]

29. Brenner, M.; Hearing, V.J. The protective role of melanin against UV damage in human skin. Photochem. Photobiol. 2008, 84, 539-549. [CrossRef]

30. Smit, N.; Vicanova, J.; Pavel, S. The hunt for natural skin whitening agents. Int. J. Mol. Sci. 2009, 10, 5326-5349. [CrossRef]

31. Limtrakul, P.; Yodkeeree, S.; Thippraphan, P.; Punfa, W.; Srisomboon, J. Anti-aging and tyrosinase inhibition effects of Cassia fistula flower butanolic extract. BMC Complement. Altern. Med. 2016, 16, 497. [CrossRef]

32. Petrillo, A.D.; González-Paramás, A.M.; Era, B.; Medda, R.; Pintus, F.; Santos-Buelga, C.; Fais, A. Tyrosinase inhibition and antioxidant properties of Asphodelus microcarpus extracts. BMC Complement. Altern. Med. 2016, 16, 453. [CrossRef]

33. Wu, L.; Chen, C.; Cheng, C.; Dai, H.; Ai, Y.; Lin, C.; Chung, Y. Evaluation of tyrosinase inhibitory, antioxidant, antimicrobial, and antiaging activities of Magnolia officinalis extracts after Aspergillus niger fermentation. BioMed Res. Int. 2018. Available online: https://www.hindawi.com/journals/bmri/2018/5201786/ (accessed on 5 July 2019). [CrossRef]

34. Chan, C.F.; Wu, C.T.; Huang, W.Y.; Lin, W.S.; Wu, H.W.; Huang, T.K.; Chang, M.Y.; Lin, Y.S. Antioxidation and melanogenesis inhibition of various Dendrobium tosaense extracts. Molecules 2018, 23, 1810. [CrossRef]

35. Lee, J.Y.; Cho, Y.R.; Park, J.H.; Ahn, E.K.; Jeong, W.; Shin, H.S.; Kim, M.S.; Yang, S.H.; Oh, J.S. Anti-melanogenic and anti-oxidant activities of ethanol extract of Kummerowia striata: Kummerowia striata regulate anti-melanogenic activity through down-regulation of TRP-1, TRP-2 and MITF expression. Toxicol. Rep. 2019, 6, 10-17. [CrossRef] [PubMed]

36. Weather Online. Available online: https://www.weatheronline.co.uk/weather/maps/city (accessed on 15 June 2019).

37. Su, T.R.; Lin, J.J.; Tsai, C.C.; Huang, T.K.; Yang, Z.Y.; Wu, M.O.; Zheng, Y.Q.; Su, C.C.; Wu, Y.J. Inhibition of melanogenesis by gallic acid: possible involvement of the PI3K/Akt, MEK/ERK and Wnt/ $\beta$-catenin signaling pathways in B16F10 cells. Int. J. Mol. Sci. 2013, 14, 20443-20458. [CrossRef] [PubMed]

38. Hong, Y.H.; Jung, E.Y.; Noh, D.O.; Suh, H.J. Physiological effects of formulation containing tannase-converted green tea extract on skin care: physical stability, collagenase, elastase, and tyrosinase activities. Integr. Med. Res. 2014, 3, 25-33. [CrossRef] [PubMed]

39. De Freitas, M.M.; Fontes, P.R.; Souza, P.M.; Fagg, W.C.; Guerra, E.N.S.; de Medeiros Nóbrega, Y.K.; Silveira, D.; Fonseca-Bazzo, Y.; Simeoni, L.A.; Homem-de-Mello, M.; et al. Extracts of Morus nigra L. leaves standardized in chlorogenic acid, rutin and isoquercitrin: tyrosinase inhibition and cytotoxicity. PLoS ONE 2016. Available online: https://www.ncbi.nlm.nih.gov/pubmed/27655047 (accessed on 5 July 2019). [CrossRef]

(C) 2019 by the authors. Licensee MDPI, Basel, Switzerland. This article is an open access article distributed under the terms and conditions of the Creative Commons Attribution (CC BY) license (http://creativecommons.org/licenses/by/4.0/). 